\title{
The Management and Challenges of Protected Areas and the Sustenance of Local Livelihoods in Cameroon
}

\author{
Cornelius Mbifung Lambi ${ }^{1}$, Jude Ndzifon Kimengsi ${ }^{1}$, Cordelia Givencheh Kometa ${ }^{1}$ \& Emmanuel Sunjo Tata ${ }^{1}$ \\ ${ }^{1}$ Department of Geography, University of Buea, Buea, Cameroon \\ Correspondence: Cornelius Mbifung Lambi, Department of Geography, University of Buea, Buea, Cameroon. \\ E-mail: lambimc@yahoo.com
}

Received: March 22, 2012 Accepted: May 13, 2012 Online Published: July 11, 2012

doi:10.5539/enrr.v2n3p10

URL: http://dx.doi.org/10.5539/enrr.v2n3p10

\begin{abstract}
The popular word en vogue today as far as the management of protected areas is concerned is the call to include local participation' and 'community development' as part of a comprehensive strategy for biodiversity protection. While much paper work has been done in the form of laid downs laws and policies, decrees have been signed on the issue of creating and managing protected areas in Cameroon for posterity, it is a hard truth that little implementation and enabling environments have been created to make protected areas in Cameroon sustainable. This paper argues that there is a need to move away from the paper work and rhetoric of "providing alternative means of survival to adjacent populations" by making this option a reality. In this context, we suggest the need for applicable and realistic laws and the effective application of these laws and the creation of an enabling environment which will gradually, without violence or intimidation, make the adjacent populations of protected areas (PAs) to evacuate the areas encroached upon and also actively take part in the process of conserving the PAs. In addition, the paper suggests the need for context-specific economic opportunities which conform with the socio-economic and cultural realities of the communities in question.
\end{abstract}

Keywords: protected areas, local livelihoods sustenance, challenges, Cameroon

\section{Introduction}

The forest ecosystems and wildlife sanctuaries are continuously undergoing degradation from the growing population pressures of the adjacent communities. So, the increasing human population today, normally, calls for the use of more resources; the natural consequence has been the excessive exploitation of natural resources which are signatures of resource degradation. As this has been the bedrock of the threat to nature, natural habitats or the environment senso lato, the need for conservation or nature protection has thus become the prime force for the creation of protected areas as forest reserves, national parks and wildlife sanctuaries. In Cameroon as elsewhere, this is the remedial solution which is generally adapted in order to mitigate the degradation and depletion of our natural resource base.

As a result of the decline in wildlife populations (Nomsa, 1992), the management approach adopted by most African countries for biodiversity conservation has been the development of protected areas (PAs). So, some African nations have established extensive networks of protected areas which play an essential role in biodiversity conservation. Sub-Saharan Africa has over 1100 national parks of which 36 are designated World Heritage Sites (WCMC, 2004). Since 1970, the total PA coverage in Africa has increased nearly two-fold, and it now encompasses 3.06 million $\mathrm{km} 2$ of terrestrial and marine habitats (WCMC, 2004). A protected area is an area (land, water and forest) allocated for biodiversity conservation through either international or local legislation. These areas are very useful for ecotourism development which could usher in a number of socio-economic and environmental benefits to the society in question if they are well managed. Although the expansion of protected area coverage in Africa over the past 30 years is extremely encouraging, the lapses in the implementation of policies to ensure the sustainable management of these PAs have remained.

A seemingly greater proportion of the world's conservation sites or protected areas are found within the African continent and at the same time, they face the greatest challenges in terms of their management and sustainability. These challenges range from weak institutional support to secure livelihoods which are connected to the activities of the PAs and the need to open up access routes and communication services to these areas which are mostly remote (Darwin Initiative for the Survival of Species, 2004). Oldfield (1988) asserted that in order to 
guarantee the sustainable management of PAs, 'new ideas are needed' in biodiversity conservation because the local populations generally see these protected areas as government-imposed restrictions on their traditional rights. The redistribution of the benefits emanating from conservation and the resolution of conflicts between conservationists and local communities are central elements in the highly solicited 'new approach' to conservation in much of Africa (Baskin, 1994).

Cameroon (Figure 1) is ranked today as the second richest country in terms of biodiversity in Africa; it is thanks to her endowments of flora and fauna. This has given rise to the possibility for the development of a number of wildlife sanctuaries.

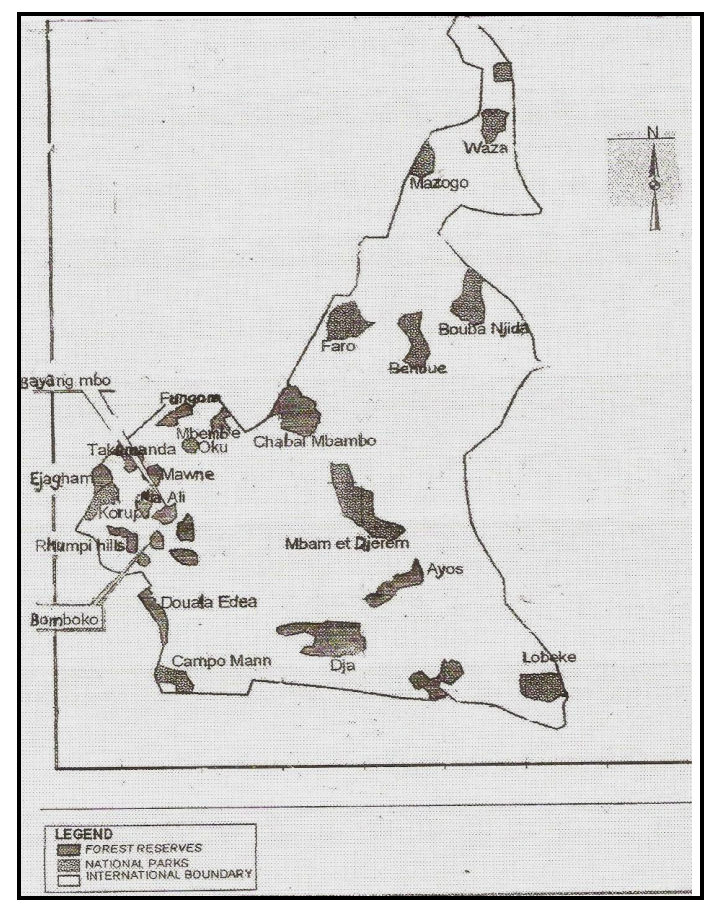

Figure 1. The spatial distribution of national parks and forest reserves in Cameroon

\section{The Problem}

The galloping population growth is a reality of our time. This anomalous growth impinges very heavily on resource use through excessive exploitation in a bid to satisfy the growing human demands and economic development. This over exploitation therefore calls for a need for the protection or conservation of some resources in order to meet the needs of the growing future generation. So conservation or protection of forest and wildlife resources is a laudable effort. But the problem is that the protected areas which are forests and wildlife sanctuaries were created without providing any alternatives whatsoever for the local or indigenous populations within the protected areas. This unresolved problem dating back from when the populations were small have today assumed a significant magnitude in the face of the rising population.

Man, the world over is dependent on the resources of his immediate environment. However, when the indigenous people are denied their basic livelihoods through administrative creations that hinder them from depending on their natural resources, then there is an unresolved problem which only gets bigger as the years go by. This is the situation of most protected areas in Cameroon.

Perhaps, because the creation of nature reserves go in line with some of the terms of Cameroon's diplomatic relations with some international organizations and the western world, their creation could, somehow by our estimation, be interpreted as an indirect attempt to resolve the animal and plant population problem in some of the developing countries of Sub-Saharan Africa. The carving out of huge portions of land for conservation would mean that the environment that provided for the livelihoods of the indigenous populations is drastically reduced. This reduction, evidently, increases the carrying capacity of that environment since the large human population will be forced to depend on a much more reduced surface area. The question that arises therefore is: how long can this reduced surface area continue to sustain the growing population? When these populations are deprived of their basic livelihoods, it logically means one of two things. Either you stay behind, fall sick and die since you 
cannot pay for food and adequate treatment (this applies especially to the aged population), or you migrate to other areas or hollow frontiers with better economic opportunities (especially the active populations). This is the background of the problem surrounding the whole concept of protected areas, nature reserves or national parks. From the perspective of the international community, the way forward has been the Concept of Sustainable Development in accordance with the Brundtland Report of 1987 and the Rio Earth Summit of 1992.

\section{Current Situation of Protected Areas (PAs) in Cameroon}

Perhaps, the concern about the creation of PAs in Cameroon came up as a result of the need for sustainable development which is a product of the 1987 Brundtland Report and the 1992 Rio Earth Summit. From this perspective, the Cameroon Government re-enforced legislation on Nature Reserves. In 1992, the Ministry of Environment and Forestry was Created in Cameroon. Two years later, Law No 94/01 of 20th January 1994 to regulate wildlife, forest resources and fisheries was enacted to become what was known as the 1994 Forestry Law. A year later, Decree No 95 of 466 PM of 20th July 1995 established conditions of wildlife regulations while in 1996, the National Environment Management Plan (NEMP) was created which was aimed at conserving more resources in the country by increasing the amount of protected areas from 20 to $30 \%$ so that all the major biomes in the country could be represented. Thus, the National Parks and Protected Areas (PAs), cover a surface area of more than 633000ha.

Christened as "Africa in miniature", Cameroon has over 30 protected areas with at least one in each region of the country consisting of forest reserves (Figure 2a), wildlife sanctuaries (Figure 2b), national parks and zoos (Tchindjang \& Fogwe, 2009).

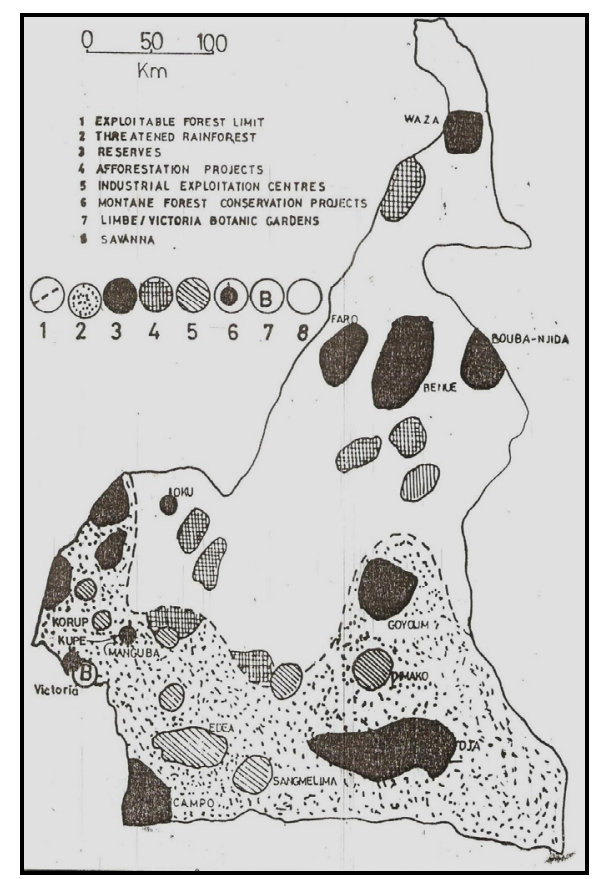

Figure 2a. Forest reserves in Cameroon

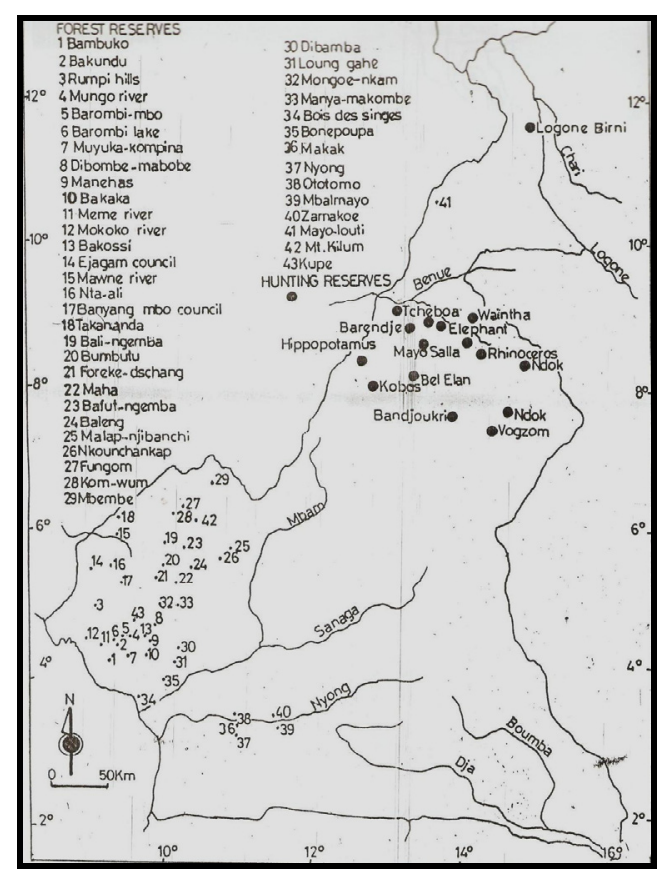

Figure 2b. Wild life reserves in Cameroon

After the Earth Summit of Rio de Janeiro in 1992, the government of Cameroon, in adhering to the commitments of this summit, through Decree no 92/069 of 9 April 1992, created the Ministry of the Environment and Forestry (MINEF). This ministry had the mission to guarantee the sustainable exploitation of biodiversity and the sustainable management of nature reserves to ensure environmental sustainability.

Since 1992, the need to perpetuate conservation endeavours has been materialized by the creation of major conservation areas in forest zones, the redefinition of objectives and statutes for protected areas, the development of partnership in the management of protected areas and the sharing of benefits among the various stakeholders in the sector (MINEF, 2002).

The government of Cameroon has a well defined national forestry policy which is underpinned by a number of legislative and regulatory acts. Laws relating to the management of PAs, specifically the forest date as far back 
as 1974. The main legislative acts are Ordinance No. 75/18 of May 1975 and its implementing decrees; Law No. $81 / 13$ of 27 November 1981 to lay down the forestry, wildlife and fishery regulations and its implementing decrees; and Law No. 94/01 of 20 January 1994 to lay down the forestry, wildlife and fishery regulations and its implementing decrees. Law No. 96/12 of 5 August 1996 lays down the legal framework for environmental management and main guidelines and ministerial norms (National Environment Management Programme, National Forestry Action Plan, Emergency Action Plan, Convergence Plan, National Anti-poaching Strategy, Elephant Management Plan, Forest and Environment Sector Programme). Despite these laws, the possibility for the provision of alternative means of livelihood has not been effectively implemented and this is a major setback in the process of ensuring the sustainable management of PAs.

\section{Challenges of Protected Areas in Cameroon (Missing Links)}

The whole idea of creating protected areas in the form of wildlife sanctuaries, forest reserves, zoos and national parks remains a nightmare to adjacent communities in Cameroon. So, many unanswered questions which linger in the minds of the villages or adjacent communities and continue to embitter them are swept under the carpet by the institutions that preach and "enforce" conservation of this natural heritage in Cameroon.

At the time of creation of protected areas, nature reserves or parks, the existing populations within the nature reserves or parks were small. Yet, at that time, no alternative provisions were made for local livelihoods. This could be achieved by total resettlement schemes and the provision of alternative sources of income and livelihoods. And now, population has grown astronomically in some of these national parks or nature reserves. Perhaps some important questions to ask at this juncture are as follows:

$>\quad$ Is Cameroon serious about the aspect of nature conservation or are we simply joking?

$>\quad$ Do we recognize that mankind obtains his basic livelihood from his environment?

$>\quad$ What benefits accrue to the people? In Cameroon apparently, the answer blows in the wind given our neglect of the plight of the indigenous people.

$>\quad$ What is the interest of conservation to the local population?

$>\quad$ Where should they farm and hunt?

$>\quad$ Where should they obtain timber and Non Timber Forest Products (NTFPs) for food and other necessities for human survival?

To deny mankind all of these basic necessities imply that they should go into extinction. Should we preserve plants and animals at the expense of humanity when biblical literature from the book of Genesis tells us that God gave man dominion over the plants and animals of the earth, the birds of the air, and the fishes from the water? It then becomes an ethical issue. Should we go into extinction in order to conserve plants and animals for their own sake? Are the plants and animals meant for man or man is meant for plants and animals?

Nature's intricate link between the environment, man and resources is therefore derailed as the functional relationship between these does not have its relevance. Even the native American-Indian says that the mountains cared for the forest, the forest cared for the waters, and the waters cared for the fish. This chain provides for human livelihood. To overturn this chain of events calls for the destruction of ecosystem and the food chain webs. In the face of these contradictions, perhaps nature reserves, protected areas and national parks, although well intentioned and practicable in many parts of the world are, indeed, planning mistakes exercised in futility in most parts of Cameroon as most parks have been undermined in man's quest to survive within his God-given milieu.

In a book on nature reserves around the globe entitled "Protecting Indigenous Peoples in Protected Areas: The Law of the Mother," Njiforti and Tchamba (1993) in the article "Conflicts in Cameroon, Parks for or Against People" asked whether trees and animals were meant for man or man was meant for trees and animals. This question arose because by decree of 1968, a National Park was created for the conservation of plants and animals in the Sudano-Sahelian Region of North Cameroon. The indigenous people in this water-stressed environment, with their low rainfall which comes in 3-4 months, only short cycle grain crops like maize, millet and sorghum are grown. And, while the population is not allowed to hunt the animals from the Parks, the hungry animals from the Park invade the neighbouring farmlands, damaging crops thereby undermining the meagre rural livelihoods. When the rainfall amount drops significantly in these areas, the meagre grain harvests are threatened. With an adverse climate on the one hand and nature conservation of wildlife on the other, man is at risk as he suffers from a double tragedy of animal destruction of crops and exposure to famine and also the threats of crop failure by a capricious climate. So therefore, nature and government have denied the indigenous people their basic livelihoods and the basic means of rural sustenance. 
And what is more? The same animals which are protected are hunted by Europeans under license at given times of the year. So, the ethical question is whether the pleasure-seeking holiday makers from Europe should hunt for pleasure while the indigenous people are not allowed to do so for basic survival? This is another ethical question. So the logical question is, how far can we go with conservation when it relates to the high handedness of the state against an impoverished indigenous people who look onto the state for certain amenities to make life more comfortable? Conservation in this sense remains a paradox of all times. And this state of affairs calls for a review of our objective of conservation against the welfare of humanity. This is an example, par excellence of the paradox of value and an insult to humanity. Here are some excerpts which could be used to drive our lesson home.

1. "We didn't even know that parks existed until the authorities started sending our people to prison for hunting. That was when we found out that we couldn't hunt where we used to hunt and that we were not allowed to hunt the wild animals that were killing our livestock."

2. The hunting zones surrounding the parks are "rented almost exclusively to foreigners for commercial safari hunting. This has exacerbated tensions as villagers attempt to farm or graze it. Rapidly expanding human populations cause additional pressures."

3. "You cannot count how many of our sheep, cattle and goats have been taken by wild animals from over there."

4. "If the authorities come to the village, it is to arrest somebody because he has hunted or grazed his animals in the park."

5. "What really worries me about your so-called park is the fact that we sometimes go without food because baboons have raided our farms. We have to depend on charity from other people in the village. This is what the park means to us."

6. "So you think that for our future generations to see what we see today, we don't have to eat? How will this generation come about any way, when people are dying of hunger?"

Another excellent illustration which readily comes to mind is the Bayang-Mbo Wildlife Sanctuary and the Southern Bakundu Forest Reserve. In graphical terms, Ewane (2006) refers to the Southern Bakundu Forest Reserve as a continuum of cocoa farms. In the same way, the creation of this forest reserve in 1937 and its approval by decree No. 22 of $25^{\text {th }}$ of April 1940 without any provisions of alternative sources of survival for the indigenous and migrant populations in the area meant that the people had to exploit the forest and forest resources. And being an agrarian population, cocoa farms were opened and expanded to such an extent that the lateral expansion of farms meant the coalescence of one private cocoa plantation and the other. What becomes evident therefore is a mere succession of farms and not forest and forest resources as conceived by the founding fathers of this conservation project.

Perhaps, the cardinal lessons for us to learn from these unresolved challenges of conservation efforts mean that the top-bottom approach as used by the state has failed. So, decrees and legislation do not usually have answers to the conservation problem. The heavy and high handedness of the state cannot reasonably achieve wildlife conservation.

Furthermore, success in conservation must be predicated on a just and equitable approach in which the dispossessed populations are given viable survival alternatives. In this case, they do not need to walk back into the forest to look for their survival. Thus, the success of laws relating to the management of nature reserves or protected areas depends on how these laws align with both national development objectives and the interest of the communities adjacent to these PAs. When such laws are made applicable and acceptable by both parties, then the management of these PAs will be sustainable. However, if such an option does not address the problems of one party, especially in the case of the adjacent forest communities, all approaches to conserve and ensure the sustainability of these PAs will be fruitless. The fact that the resources of these PAs almost invariably occupy areas that are owned by different communities require some serious consideration of the property owners' rights. More so, the bottom-up approach whereby all the stakeholders are involved in the conceiving, planning and execution stages remain a viable way forward for nature conservation. In addition, the benefits of such conservation measures must be ploughed back to the population as an incentive and insurance against the violation or intrusion into the parks or nature reserves.

The notion of protected areas, generally a colonial fabrication, seems controversial as it presents and represents the western interest. The local populations generally view these PAs as zones carved out for the "white men" who can visit them, get medicinal plants in the name of carrying out research, hunt and do whatever they want while the local populations are generally deprived of such access (Njiforti \& Tchamba, 1993). The local people 
are often rewarded in such a deal with embargoes and restrictions placed on them not to encroach there, knowing fully well that the socio-economic and cultural life of these people depend on the PAs. Owing to the need for survival, the communities almost invariably "defy" such embargoes and the obvious repercussion is their imprisonment. This state of affair which reduces the communities to strangers in the land of their birth has persisted for a long period of time and is the main reason behind the numerous unsuccessful conservation stories about protected areas in Cameroon.

The mere fact that PAs were generally created or carved out without the consent of the villagers is a signal of failure in their sustenance. As the saying goes, "everyman is strong in his home", such an action of disregard insults the existence of these villagers and their so much cherished institutions, and destroys the possibility for mutual understanding among the two parties (local population and conservation authorities). In addition, the restriction of the indigenous people, who, in effect, are the owners of these PAs in favour of foreigners (especially the whites) generates feelings of resentment and compromises the possibility for dialogue, mutual understanding and conflict resolution around these PAs. In the case of national parks for instance, Njiforti and Tchamba (1993) observed that hunting zones created around the national parks of Northern Cameroon are rented almost exclusively to foreigners for commercial safari hunting to the detriment of the farming and grazing populations. This generates much tension especially in the face of increasing human populations which places much demand on the natural resource base. Sustainability cannot thrive in a conflict-ridden environment. So, conflict resolution is paramount in these PAs if the government must ensure their successful conservation.

The infringement on traditional customs, institutions and way of life of the adjacent forest populations is a major setback to the sustainability of PAs. These PAs are surrounded by adjacent rural communities whose traditions and way of life in one way or the other, are affected by the PAs. In the case of forest reserves which are found mainly in the southern parts of Cameroon, some of the forest reserves served as a source of food, fish, non-timber forest products (NTFPs), wood, and medication, and also as shrines for ancestral worship. In another dimension, in the northern regions of Cameroon, where livestock farming is a way of life, the protected areas have presented themselves as a nightmare because wild game from national parks destroy livestock and crops grown by the local population; yet they receive no compensation from the park authorities. The villagers therefore go hungry because of the so-called nature reserve. The mere fact that the present generations are reduced to hungry and dying beggars, compromise the possibility for the creation and/or existence of future generations. This defeats the concept of sustainability for people who live at the margin of basic survival.

In addition, it would seem that in trying to ensure sustainability in PAs, the sustainability of local customs and way of life of the people are compromised. The restriction of local populations to worship in their shrines and the consistent refusal of children in the North to practice hunting in game reserves erodes the way of life of the people and keeps the elderly people in these communities concerned about the future of their communities where the prowess of men is measured by how well the man can hunt game to feed his household. The mere explanation of the need to preserve some plant and animal species from extinction which shows applicability only to the indigenous people while foreigners have seemingly unrestricted access does not speak well of this conservation move since it presents an egocentric face.

It is a widely held view that poverty exacerbates environmental degradation and environmental degradation, in turn, exacerbates poverty. This notion is true because the failure to secure a livelihood for the population means that they must survive by getting to the PAs and in so doing, they may degrade the resources of these PAs. In addition, the absence of basic amenities militates against the drive towards nature conservation. How do you explain the fact that the government restricts people from harvesting medicinal plants when they have failed to provide health centres to the communities in question? A traditional healer retorted: "... when people decided that we should not get anything from the park, did they know that we do not have a hospital? " (Njiforbi \& Tchamba, 1993).

This question shows the dire need for basic medical services which are conspicuously absent in most of these adjacent communities which have decided not to complain, but to draw from their natural resource base to survive healthwise. It would only be an outright provocation and an ignition of conflict to stop them from getting traditional medication from the PAs when the government has not given them a health centre or any form of health facility.

Prior to the creation of PAs, some traditional laws existed which governed the usage of most of the resources in these PAs. These institutions were respected by the villages. For instance, the present day Benoue National Park was controlled by all jaoros (sub rulers) under the Lamido (Paramount Ruler) of Ray-Bouba and laws were passed on the type of animals which should not be hunted. The local people were restricted from using the 
lamido's hunting ground and the chief hunter often gave instructions on when and what to hunt or fish from the streams. These laws were all respected. It would have been logical that the strive for conservation would make use of the local traditional institutions by enforcing them to make them work well - a situation that is analogous to the British Colonial System of "Indirect Rule" which made use of local institutions and administration to function. Disregarding these institutions instead leads to conflicts between the traditional administration and the government.

There has been much paperwork on the need for environmental sustainability with little application in our Cameroonian landscape. The government of Cameroon has been very efficient in putting in place institutions which are charged with the management of nature reserves. Ironically, however, these institutions have not been backed by the effective implementation of the major problem affecting PAs, their continuous exploitation by adjacent communities who are left with no alternative ever since the creation of these PAs.

Furthermore, the issue of duplication of functions is also a cause for concern in Cameroon. One wonders why there is a Ministry of Environment and Nature Protection (MINEP), and Forestry and Wildlife (MINFOF) which are manned by two ministers with their defined goals which, evidently overlap and generate conflicts and a duplication of functions. Logically, MINFOF should be a subset of MINEP, that is, a Department of Forestry and Wildlife under MINEP. The continous duplication of functions by creating these two related ministries could be held responsible for the protracted inactivity in effectively implementing the needed development. This is because both parties see some functions as the obligation of the other and not theirs.

While the number of protected areas, especially national parks has increased, their contribution to the development of local livelihood is retrogressing. The question we propose is as follows: does the government want the PAs to survive at the expense of human population? This paper does not oppose the need to create PAs. Instead, it begs for the need to revisit this issue of multiplying related ministries while doing practically nothing to implement the clause of providing alternative survival means to the adjacent population. After all, development that does not centre around the welfare of the people is no development. Therefore, priority should not be to create PAs but to ensure that they are sustainable. This is crucial because the missing link in ensuring the sustainable management of PAs in Cameroon can impair the attainment of Vision 2035 which aims at transforming Cameroon into an "Emerging Economy by 2035".

In addition, the remoteness of the communities close to PAs imply that a majority of them are naïve. So, they find it difficult to question why they are deprived of their resources with no alternative provided to them. Given this state of affair, it is obvious that there is a need for a paradigm shift in the process of sustaining PAs through the implementation of a wide framework which integrates the need to preserve these PAs while improving the welfare of the vulnerable and evidently the disgruntled communities which are found adjacent to these PAs.

\section{The Future}

Given that the creation of a number of related ministries such as MINEF and MINFOF which presents itself as a missing link in terms of the implementation of duties related to the conservation and the management of PAs, there is a need to reduce the duplication and multiplication of functions of related ministries and to draw a dichotomy in their functions. In this respect, it is suggested that a single ministry - the Ministry of Environment and Nature Protection should be maintained. This ministry will, in turn, have departments such as the Departments of Forestry and Wildlife among others. This will reduce the issue of duplication of functions and the virtual overlooking of certain duties as is seemingly the case with the Ministry of Environment and Nature Protection (MINEP) and the Ministry of Forestry and Wildlife (MINFOF).

Given that most of the PAs are found in inaccessible and remote areas, it is necessary to suggest rigorous government intervention as far as the opening of good transport and communication networks is concern. This will in turn, usher in a number of socio-economic opportunities which are less dependent on the PAs. It will reduce the over reliance on PAs as a source of livelihood to the population.

PAs are very good ecotouristic sites and their presence could be very instrumental in the development of the Ministry of Tourism (MINTOUR). MINTOUR could therefore play a key role in protecting these PAs and in generating some income which could be used for capacity building and in the training of the local populations on their chosen economic activities which are non-dependent on PAs.

The clause on providing alternative means of survival continues to be mentioned in most documents related to the management of nature reserves with little implementation. This study suggests that the law on the sustainable management of PAs should not just be passed and spread on papers without seeing to it that the aspirations of the vulnerable, the poor and natural resource-dependent adjacent populations have been taken into consideration. 
The much talk and sensitization should be backed by action because it is not logical to stop people from encroaching into a PA when you have not given them an alternative direction for survival.

In addition, it is necessary to warn that the implementation of the strategy of providing alternative economic opportunities should not be imposed on the population. Context-specific economic opportunities which conform to the socio-economic and cultural realities of these areas should be put in place. The people should be consulted to choose from the options presented what they would like to do if they are given the opportunity. This process should be based on dialogue for a mutual understanding. The reason is that there are some disparities in the choices of the local populations and this will be governed by their socio-economic and cultural environments. Therefore, a context specific approach in providing their alternative choices is necessary because their choices will also be governed by the socio-economic and cultural realities of the areas.

Since the provision of alternative livelihood requires huge financial expenses, there is a need to create a special fund which will be used to train the local populations on their preferred economic activities, the need to assist them with some capital to start up the trade so as to ensure that they survive in these activities without affecting the PAs. This is what is obtained in the USA and Canada where the native Indians are paid some money for their basic livelihoods. The local population should be trained in their areas of interest.

In creating PAs, the areas reserved for communal exploitation should be carved out taking into cognizance, the fact that the population will grow as the years go by. Therefore, the buffer zones created should be done with respect to the projected population growth rate. In buffer zones where exploitation is allowed, it is necessary to grant equal access to the local populations especially in the case of hunting around the national parks. This will diffuse the tensions that accompany the bias in access to the national parks which seem to favour foreigners and influential persons.

It is necessary that the government should train skilled professionals who are versed with the emerging trends of nature conservation. The personnel in question should be equipped with the basic skills to make them more integrated into the local life of the population. This seemingly friendly approach will improve the relationship between the conservation officials and the local population who, till this moment, still view them as enemies. It will go a long way to improve the conservation of PAs and ensure that they become sustainable. The conservationist should organize village sessions where the people dialogue on the importance and need for a PA. Such sensitization campaigns should target the need to make the local population to see and accept the multiple benefits of conserving the forest and receiving adequate compensation to cater for their basic livelihood needs.

Since traditional conservation institutions existed prior to the carving out of these PAs, it seems logical to study these traditional norms or laws and see how the laws and the institutions can be reinforced to make PA administration more representative and realistic. This action would succeed better than the option of trying to bypass and erode the laid down institutions that existed since the local communities still attach much reverence to it. Where some laws are conflicting, it will be necessary for the government representatives and the traditional authorities to strike a balance through dialogue.

To ensure an effective conservation and sustainable management of PAs, it is necessary that after due consultation with the local communities, the government should ensure that the regulations and laws in force are adaptable, applicable, acceptable and enforceable with emphasis on a participatory approach which could meet the needs and aspirations of the communities. A paradigm shift from mere preaching to effective action could be very instrumental in attaining one of the goals of maintaining environmental protection as spelt out in Cameroon Vision 2035.

\section{Conclusion}

The management of PAs has witnessed some evolution, moving from the declaration of the potential areas as conservation and thus protected areas as a way of separating people from the wildlife resources, taking cognizance of the fact that "people could not manage the resources sustainably." Today, it has moved to a situation where there is the increasing recognition of the need to budget with the livelihood needs of adjacent communities in mind. Ironically, however, this much needed move continues to remain on paper in the form of decrees. The need to match words with action by designing context-specific poverty alleviation and PA management measures for communities adjacent to these PAs is very eminent if Cameroon must continue to boast of her rich biodiversity now and in the future. The sustainability of PAs in Cameroon lies in a balance; the reliance on continuous talk with little implementation will only affect our biodiversity; but the effective implementation of the clause on providing alternative livelihood needs will guarantee sustainability in the management of these PAs. The conclusion drawn here is that some people have either become fanatics on the issue of conservation and the creation of protected areas as they are carried away by the slogan of environmental 
protection without laying viable bridges or ground works for it to succeed. In another dimension, the notion of greed and outright neglect of the local communities and the failure to put them on a dialogue table for a plausible solution remains immaterial to them. But what is certain is that the future of these PAs is threatened as long as these local populations are not made to feed well, earn incomes, have good medical facilities or are provided with a means of survival. These planning lapses call for a critical examination and a rethinking of the sustainability of protected areas in Cameroon.

\section{References}

Baskin, Y. (1994). There's a New Wildlife Policy in Kenya: Use it or Lose it. Science, 265,733-4.

Darwin Initiative for the Survival of Species. (2004). Conservation Management Training and Capacity Building in Sub Saharan Africa. International Centre for Protected Landscapes and the Centre for Environment, Agriculture and Development. Project Reference Number 162-13-002. Annual Report 2004/5.

Foahom, B. (2001). Biodiversity Planning Support Programme: Integrating Biodiversity into the Forestry Sector. Cameroon Case Study. Paper Prepared for an International Workshop on Integrating Biodiversity into the Forestry Planning Programme held in CIFOR headquarters, Bogor, Indonesia on 13-16 August 2001.

Kameri-Mbote, P. (2005). Sustainable Management of Wildlife Resources in East Africa: A Critical Analysis of the Legal, Policy and Institutional Frameworks.

Lambi, C. M. (2001). The Impact of Human Activities on Land Degradation in Some Highland Regions of Cameroon: Implications for Development. In Lambi, C.M. (ed). Environmental Issues: Problems and Prospects, Unique Printers, Bamenda.

Ministry of Environment and Forest (MINEF): The Rumpi Hills Wildife Sanctuary Draft Management Plan. 2003-2008. Prepared with the Support of GTZ December 2002.

Ndenecho, E. N. (2005). Biological Resource Exploitation in Cameroon: From Crisis to Sustainable Management. Unique Printers, Bamenda.

Ndenecho, E. N., \& Fonteh, M. L. (2012). Fresh Water and Coastal Resource Management in Cameroon: Building Resistance and Resilience to Climate Change. Agwecams Printers, Bamenda, Cameroon.

Ndenecho, E. N., \& Mbue, I. N. (2010). Integrating Local Livelihood Sustenance Activities in Protected Area Management. The Case of the Korup National Park, Cameroon. African Journal of Social Sciences, Volume 1, Number 2, University of Buea, Cameroon. pp. 23-35.

Neumann, R. P. (1997). Primitive Ideas: Protected Area Buffer Zones and the Politics of Land in Africa. Development and Change, 28, 559-582.

Newmark, W. D. (2008). Isolation of African Protected Areas. Front Ecol Environ, 6(6), 321-328. http://dx.doi.org/10.1890/070003

Njiforti, H. L., \& Tchamba, M. N. (1993). Conflict in Cameroon: Parks for or Against People? In Kemf, E. (ed) (2000): The Law of the Mother: Protecting Indigenous Peoples in Protected Areas. Sierra Club Books, San Francisco, pp. 173-178.

Nomsa, D. D. (1992). Protecting the African Environment: Reconciling North-South Perspectives. Critical Issues, 3 (1992).

Oldfield, S. (1988). Buffer Zone Management in Tropical Moist Forests: Case Studies and Guidelines. Gland, Switzerland: IUCN.

Tchindjang, M., \& Fogwe, Z. N. (2009). Ecotourism in Protected Areas of Cameroon: Trends, Problems and Prospects. In Lambi, C.M. (ed.). Cameroon: A Country at Crisis Crossroads: An Anthology in the Social Sciences. Nab Ventures, Bamenda, Cameroon. pp. 197-221.

World Bank. (1993). The World Bank and the Environment: Fiscal 1993. Washington, DC: The World Bank. 